\title{
Ao homem que sobe montanhas: o amor em meio à polêmica na cinebiografia de Edir Macedo
}

\author{
${ }^{44} \mathrm{Eu}$, porém, vos digo: \\ Amai vossos inimigos e orai pelos que vos perseguem, \\ ${ }^{45}$ a fim de serdes verdadeiramente filhos do vosso Pai que está nos céus, \\ pois ele faz nascer o seu sol sobre os maus e os bons, \\ e cair a chuva sobre os justos e os injustos.
} (Mt 5, 44-45)

\section{Luana Ferraz}

Tiago Ramos e Mattos

\section{O amor também é um show}

Em 1967, ao publicar A sociedade do espetáculo, o filósofo, agitador social e diretor de cinema Guy Debord denuncia com veemência a midiatização da vida comum em todos os seus domínios, e, mais que isso, o quanto as relações sociais que compõem o espetáculo estão vinculadas à produção e ao consumo de mercadorias. Para Debord (1997 [1967]), a mercantilização atinge tudo: a política, a arte, as manifestações religiosas, as relações interpessoais mais insuspeitas.

O espetáculo conceituado pelo pensador nada mais é “(...) uma relação social entre pessoas, mediada por imagens", ${ }^{1}$ que, em última instância, conduz a uma negação da vida real. $\mathrm{O}$ avultamento das imagens desconhece limites e leva ao "(...) recalcamento de toda verdade vivida, diante da presença real da 
falsidade garantida pela organização da aparência”. ${ }^{2}$ Abolidas as fronteiras entre o verdadeiro e o falso, temos, pois, no discurso espetacular, um mundo que se apresenta como real.

Toda essa construção demanda, naturalmente, elementos para uma persuasão especializada. No espetáculo, o jogo assume o centro do discurso. Desse modo, reúnem-se expedientes retóricos que engendram a diversão e a fantasia; que movem a imaginação e os afetos. Sustentado por técnicas e meios de comunicação de enorme abrangência e alto poder de persuasão, o entretenimento (do latim, inter $=$ entre; tenere $=$ ter) se imiscui em todas as áreas de nossa sociedade midiatizada e se coloca entre o homem e o mundo.

Os profissionais do entretenimento se valem das convenções, da doxa, das sensações e da disponibilidade emocional de seus auditórios para (re)criar mundos de sonhos, medos, dores e prazeres; formas de pensar, de agir, de se relacionar. Assim, seus discursos mais impressionam que facultam a expressão. Ademais, dirigem-se sempre a um grande número de pessoas, o maior possível, à "massa". Filmes, videoclipes, histórias em quadrinhos, telenovelas, séries, jogos eletrônicos, romances populares, entre outros, materializam discursos que se propõem a atrair e capturar sentidos e emoções, por projetarem, como sugere Gabler (1999), uma realidade interior composta por valores, desejos e temores de um vasto grupo social.

Não se trata, no entanto, de imposição, como se poderia pensar, mas de acordo. As "criações" midiáticas, de maneira geral, diminuem as tensões, afastam o "excesso de realidade" que, algumas vezes, pode levar ao adoecimento do corpo e da mente. Dessa forma, as histórias "fabricadas" e os ídolos "construídos" pelo entretenimento estabelecem-se como elementos espetaculares diante de uma passividade parcialmente consentida.

Trata-se da busca pelo prazer. Logo, entendemos que animar as emoções é função medular da persuasão especializada dos discursos do espetáculo. As imagens criadas pelos discursos do entretenimento funcionam, por conseguinte, como combustível para as paixões. E como poderíamos nos esquecer do cinema ao mencionarmos o nexo entre os arranjos plurissemióticos, a percepção sensorial, a construção de imagens mentais e o movimento passional?

Em um dos capítulos que compõem a antologia $A$ experiência do cinema (1983), organizada por Ismael Xavier, Munsterberg afirma que "o principal objetivo do cinema deve ser retratar as emoções". ${ }^{3}$ A essa declaração nos cabe acrescentar: retratar e suscitar emoções. O próprio autor fará essa observação

2 Ibid., p. 140, grifo do autor

3 Munsterberg, 1983, p. 46 
Ao homem que sobe montanhas: o amor em meio à

polêmica na cinebiografia de Edir Macedo

em um segundo momento de seu ensaio, quando distinguirá dois grupos de emoções reconhecíveis nas produções cinematográficas:

de um lado, as emoções que nos comunicam os sentimentos das pessoas dentro do filme; do outro, as emoções que as cenas do filme suscitam dentro de nós e que podem ser inteiramente diversas, talvez exatamente opostas às emoções expressas pelos personagens. ${ }^{4}$

No cinema, mais que no teatro, a atenção do auditório é mantida pelas interações emocionais. Na tela, as ações das personagens são determinadas por afetos que lhes dão unidade e significado. As experiências afetivas dos sujeitos que desempenham o papel dos interlocutores da narrativa fílmica dialogam com os valores e com as tendências emocionais do auditório de espectadores, e são vários os artifícios aplicados para que as emoções discursivamente construídas atinjam os sentidos e as mentes dos que as acompanham do "mundo real": roteiros cuidadosos, permeados, muitas vezes, por "frases de efeito"; sons; cores; jogos de câmera; além do trabalho do ator, dos movimentos amplos ou sutis, dos detalhes da expressão, da boca, dos olhos, de cada franzir de testa que dá uma nuance diferente à emoção.

As paixões que movem as personagens nos filmes são codificadas e, percebidas pelo auditório, produzem estímulos relativamente previsíveis, uma vez que as emoções e sua expressão obedecem a lógicas pessoais, mas também sociais, conforme nos recorda Le Breton (2009). Na maior parte dos casos, as paixões reconhecidas pelos espectadores provocam paixões-resposta equivalentes:

simpatizamos com quem sofre e isto significa que a dor que vemos se torna a nossa própria dor. Compartilhamos da alegria do amante realizado e da tristeza de quem chora o seu luto; sentimos a indignação da esposa traída e o medo do homem em perigo. ${ }^{5}$

Em outros, entretanto, o auditório superpõe aos eventos uma outra paixão, diferente daquela em evidência na tela:

Vemos alguém insuportavelmente afeitado, cheio de solenidade, e esta pessoa nos inspira a emoção do humor: é o senso do ridículo comandando a nossa reação. O filme melodramático nos mostra um canalha 


\begin{abstract}
perverso e mal-intencionado, mas longe de imitar a sua emoção reagimos ao seu caráter com indignação moral. Vemos a criança alegre e risonha colhendo frutinhos à beira do precipício sem se dar conta de que vai cair se o herói não a salvar no último instante. É claro que sentimos a alegria da criança junto com ela, do contrário, nem entenderíamos o seu comportamento; mas a sensação mais forte é a do medo e do horror que a própria criança ignora. ${ }^{6}$
\end{abstract}

As paixões apresentam-se, assim, como "modos de ser" e "respostas a modos de ser", como propõe Meyer.7 Tal qual dependem de nossos desejos e valores, de como nos sentimos e expressamos esse sentir, também se referem a um ajustamento ao outro, à representação que ele nos apresenta. No cinema isso é bastante claro. Estamos sempre diante de um "outro" sujeito a questionamentos e qualificações. Por esse motivo, no discurso cinematográfico a dimensão passional é sempre exuberante.

Toda essa pujança pode ser conquistada pelo recurso a diferentes paixões, dentre as quais elencamos, certamente, as que foram selecionadas por Aristóteles na composição de sua Retórica (2005), pois seriam as responsáveis por levar os homens a mudarem suas opiniões diante de um discurso: cólera, calma, temor (medo), segurança (confiança), inveja, impudência, ódio, vergonha, emulação, compaixão (piedade), favor, indignação, desprezo, e a que mais nos importa neste capítulo, o amor.

Na concepção aristotélica, o amor é a paixão oposta ao ódio. Como somos capazes de odiar àqueles com os quais não temos nenhuma ligação pessoal, apenas por imaginarmos serem eles possuidores de um caráter que nos desagrada, também somos capazes de amar alguém a quem sequer conhecemos pessoalmente. Basta-nos supor que são generosos com os que merecem benefício, corajosos e justos acima de seus interesses individuais. Mais ainda serão dignos de amor se, além de gozarem de boa reputação, forem bons diretamente conosco ou com os que nos são próximos, a quem queremos bem.

Trate-se, como vemos, de um vínculo de identidade parcial, mais ou menos intenso, e de algum modo recíproco. Mas, afinal, o que é o amor? Para Aristóteles (2000), o desejo de que alguém obtenha ganhos, financeiros ou não, que lhe garantam segurança e bem-estar, para que ele seja feliz, sem que tenhamos qualquer vantagem nisso. Além da disposição para ajudá-lo a conseguir tais benesses quando nos for possível fazê-lo.

Ibid., p. 52

Meyer, 2000, p. XLVII 
Particularmente, amamos aqueles a quem respeitamos, a quem louvamos as qualidades, aos que se alegram com nossas vitórias e se entristecem com nossas dores, aos amigos de nossos amigos e, sobretudo, aos que se mostram capazes de amar intensa e desinteressadamente. E que, claro, acreditamos sentirem o mesmo em relação a nós. Em suma, aqueles com quem compartilhamos valores, interesses e intenções.

O amor faz parte, portanto, da consciência biográfica de cada um de nós. Os outros têm importância em nossa vida assim como gostaríamos de ter importância em suas vidas. Não são raros os momentos em que sentimos a necessidade de nos sentirmos amados pelo olhar do outro. Trata-se da informação de si mesmo na consciência amorosa do outro. Nesse sentido, anônimos e famosos não se diferenciam. Uma personagem biografada, que, eventualmente, tem sua vida levada ao cinema, também buscou durante sua história ser amada, por alguma perspectiva, aos olhos de seus contemporâneos. Na cinebiografia, tem-se, pois, a chance de ofertar ao auditório uma perspectiva amplificada, mantida pelo "efeito de verdade" do espetáculo, a partir da qual personagens comuns podem tornar-se heroicos e apaixonantes. Pensando nisso, passamos a algumas observações sobre a relação biografia e cinema.

\section{Cinema e biografismo}

Cinema é uma forma bem conhecida de arte: a $7^{a}$ arte. O biografismo se não é ciência, dispõe de uma estrutura de arte: "vida de uma pessoa (acima de tudo) narrada com arte por outra pessoa".

O cinema goza de características muito particulares como nos acrescenta Magalhães em detalhes:

Quando se fala em cinema, é preciso lembrar que existem algumas características muito específicas ligadas estritamente a essa arte. As estéticas, por exemplo, pelas sequências ligadas por figuras, pela mobilidade e flexibilidade da câmera, pela homogeneização visual, pelos gêneros, que se traduzem por linguagem específica para cada um. As características narrativas apresentam técnicas que aproximam a personagem do espectador, a linearidade ou não da história, a homogeneidade (centrada em um personagem principal ou casal) ou heterogeneidade

8 Vilas Boas, 2007, p. 20 
(vários personagens), os conflitos que emprestam impacto dramático, a coerência narrativa, a clareza, a transparência. ${ }^{9}$

O biografismo pode se expressar em $1^{\text {a }}$ pessoa - caso da autobiografia - e/ ou em $3^{\text {a }}$ pessoa - caso da biografia. Essas duas características enunciativodiscursivas são possibilidades narrativas que podem intercambiar posições: a fronteira da narração pode ser esmaecida pela personagem biográfica, que pode se confundir com o autor da proposta biográfica - pretensão autobiográfica. $\mathrm{Na}$ autobiografia escrita, por exemplo, autor, personagem-protagonista e narrador disputam o lugar de orador: orador único da própria enunciação.

No caso do cinema, o narrador pode ser a personagem biografada - que narra em $1^{\text {a }}$ pessoa, mas esse narrador não é o autor já que o cinema goza de certa criação coletiva, que se hierarquiza pela visão do diretor do filme. Portanto, a biografia e, mais especificamente, a autobiografia seriam possíveis no cinema? Lejeune relativiza a questão e, ao considerar personagens biográficos no cinema, desenvolve a seguinte afirmação:

Dentre os gêneros referenciais, o cinema se presta melhor à biografia do que à autobiografia. Ou menos mal: se o problema da expressão do sujeito desaparece, o problema do valor de verdade permanece. Vimos inúmeros Mozart ou Napoleão e nenhum deles era "o verdadeiro". ${ }^{10}$

Segundo Lejeune, o sujeito autobiográfico está inerentemente conectado a certas propriedades da linguagem: "à possibilidade de fundir em um único significante, 'eu', o enunciador e o enunciado". ${ }^{11}$ Todavia, no cinema o sujeito autobiográfico aparecerá mais pela narração do que por um cinema estritamente autobiográfico. Um filme como Sartre par lui-même (1976) [Sartre por ele mesmo] é um filme biográfico, entretanto, está mais para um filme-entrevista, em que o autor não é o Sartre propriamente dito, mas Astruc e Contat.

Portanto, há uma impossibilidade para o cinema genuinamente autobiográfico, que Lejeune (2014) chama de "Cine-mim" - "autobiogra-filme", ${ }^{12}$ que, a exemplo da autobiografia escrita, resgate um valor de verdade:

O Problema principal me parece ser o valor de verdade. O cinema autobiográfico parece estar condenado à ficção. Não posso pedir ao

9 Magalhães, 2016, p. 19

10 Lejeune, 2014, p. 268

11 Ibid., p. 263

12 Ibid., p. 257 
Ao homem que sobe montanhas: o amor em meio à

cinema para mostrar o que foi meu passado - minha infância, minha juventude -, posso apenas evocá-lo ou reconstituí-lo. A escrita não tem esse problema, pois o significante (a linguagem) não tem nenhuma relação com o referente. A lembrança de infância escrita é tão ficcional quanto a lembrança da infância reconstituída no cinema: mas a diferença é que posso acreditar e fazer acreditar que é verdadeira quando a escrevo, pois a linguagem não imita a realidade. ${ }^{13}$

Segundo Lejeune, o cinema goza de certa desvantagem por poder ser documental e sua imagem estar sempre ligada à realidade: "A criança que deve representar minha infância, o adulto a quem delego esse papel, as cenas que reconstituo não são de fato a realidade que querem ser". ${ }^{14}$

O cinema, por ter seu lugar assentado na ficção, dificulta a expressão de um cinema autobiográfico. Contudo, não exclui, na sua essência, a presença do sujeito autobiográfico, que pode aparecer por meio da narração autobiográfica e/ou da personagem autobiográfica.

A diferença entre o gênero biografia e autobiografia aparece também no cinema ao considerarmos que contar a história de uma personagem real - em $3^{\text {a }}$ pessoa - é uma possibilidade mais atraente para um auditório espectador do que um diretor de cinema contando a própria história em $1^{\text {a }}$ pessoa, como sugere a autobiografia no cinema. A cinebiografia, portanto, é uma possibilidade real, que goza de maior adesão do auditório de cinema de um modo geral.

A biografia, por ser uma possibilidade mais concreta de viabilização no cinema, deve ser aprofundada, principalmente pela possibilidade, conceituação e concepção biográfica e biografemática, como veremos a seguir.

\section{Biografia: o biografema}

Biografia é a escrita da vida: uma descrição e uma contemplação de nossas vidas que não são estáticas. "Eu” só existo diante de um "você". Uma biografia canônica captura a vida do indivíduo da infância à vida adulta, um grande feito do biografado ou uma fama conquistada - pode ser boa ou má -, repentina ou adquirida. Direciona-se ao mundo e para o mundo, a partir da relação do biografado com os outros, contemporâneos, que vivem o hoje como o biografado vive seu hoje: a visão de si mesmo por meio da consciência amorosa do

13 Ibid., p. 264

14 Ibid., p. 264 
outro. Destina-se aos contemporâneos, como pode destinar-se à glória junto aos descendentes.

A biografia é constituída de breves momentos vividos pelo biografado, metonímias, detalhes vivenciados, que representam uma parte do todo. Tratase da gestáltica da biografia: seus biografemas. Elementos estáticos vividos na biografia de cada um de nós, como peças de um jogo de quebra-cabeça, que compõem o todo vivido.

O termo biografema foi cunhado por Roland Barthes em seu livro Sade Fourier Loiola (1971). Barthes tentou isolar - a exemplo dos fonemas - esse elemento único e utilitário: o biografema. Tratar-se-ia de um elemento para a biografia: um olhar disperso, fragmentado da vida, onde são ressaltados aspectos que mais interessam dessa vida refratada.

Não se pode confundir o gênero biografia com os biografemas e/ou com seus biografemas. Os biografemas são a parte do todo, que segundo Pignatari (1996), compõem um biodiagrama que é a biografia. "Aproveitando a lição da linguística estrutural, podemos definir o biografema como traço distintivo de um biodiagrama, que é a biografia". ${ }^{15}$

$\mathrm{Na}$ condição do todo pela parte, a biografia apresenta algumas particularidades conceito-estruturais importantes de serem consideradas: as consciências biográficas. Para Bakhtin (2010), são possíveis dois tipos básicos de consciência biográfica. O primeiro tipo o autor chama de "aventuresco-heroico" e o segundo, de "social de costumes".

Bakhtin (2010), portanto, delineia dois estereótipos biográficos que começam a dar forma a uma possível pretensão de uma construção biográfica. O primeiro tipo baseia-se na vontade de ser herói, de ter importância na vida dos outros, a vontade de ser amado. Trata-se da aspiração à glória. É afirmar e construir sua vida na possível consciência dessa sociedade humana, tomando consciência de si na sociedade histórica e culta dos homens. Ao heroificar o outro, a personagem irá se familiarizar com ele e guiará sua imagem futura desejada, criada, à semelhança dos possíveis heróis com os quais ela se identifica.

O segundo elemento do primeiro tipo de consciência biográfica é o amor, a necessidade de se sentir amado no olhar do outro: é a sede de se sentir amado. A visão e a informação de si mesmo na consciência amorosa do outro. Enquanto os valores heroicos determinam a importância em um contexto em que os momentos fundamentais são os acontecimentos da vida privado-social, privado-cultural e privado-histórico, o amor determina a carga emocional. "No

15 Pignatari, 1996, p. 13 
Ao homem que sobe montanhas: o amor em meio à polêmica na cinebiografia de Edir Macedo

amor, o homem procura como que superar a si mesmo em determinado sentido axiológico na tensa possessão emocional pela consciência amorosa do outro". ${ }^{16}$

O terceiro elemento do primeiro tipo é a fabulação da personagem, que, ao vivenciar uma fabulação que nada conclui e mantém tudo em aberto, vivencia a alegria que emana da fabulação da vida.

Bakhtin (2010), ao nos apresentar essas questões relacionadas ao primeiro tipo de consciência biográfica, traça uma compreensão estética da relevância do outro em nossas vidas, no contexto histórico, cultural, ou em decorrência da necessidade, mesmo que inconsciente, de nos sentirmos amados, aproximandonos dos heróis de nossas vidas.

Essa forma aventuresca, heroica - o amar e o sentir-se amado e, até, glorificado pelo outro -, valores inerentes a esse primeiro tipo, como bravura, honradez, magnanimidade e generosidade são a forma mais próxima do sonho de vida.

Ao segundo tipo, o social de costumes, é dado um corte não histórico, mas social: a humanidade e seu cotidiano dos heróis vivos. Aparentemente, torna-se mais simples heroificar a personagem que morreu. Numa concepção social, o centro axiológico é ocupado pelos valores sociais e, acima de tudo, familiares. A boa glória junto aos contemporâneos, o homem bom e honesto e não a glória histórica junto à sua descendência. Trata-se da forma do cotidiano, do dia a dia e da felicidade ou infelicidade do indivíduo junto aos seus familiares.

Ambas as consciências biográficas, tanto a do primeiro tipo quanto a do segundo tipo, oferecem elementos para uma construção biográfica não-estática. Em ambas as possibilidades estruturais há oferta de elementos para uma biografia, mesmo considerando-as trabalhando simultaneamente - um levantamento de elementos dos dois tipos para a construção do narrador e da personagem, no intuito de desenvolver uma biografia que agrade em sua ingenuidade construtiva à também ingenuidade associativa do auditório, do leitor e/ou do (tele)espectador no caso de documentários televisivos ou mesmo no caso da cinebiografia.

Em meio à construção da própria imagem biográfica, que se consubstanciaria a partir da imagem de um herói, ou ainda a imagem delineada a partir do homem comum, que sofre como "eu" sofro, quais são os biografemas das nossas vidas passíveis de uma construção biográfica completa e consciente? De acordo com Pignatari (1996), a operação da construção do biodiagrama - a biografia - implicará na coleta de biografemas para a composição, organização e montagem de uma proposta biográfica.

Os biografemas são instantes biográficos, a biografia em seu estado primitivo, primário, uma lembrança, ou mesmo uma memória falsa de uma determinada

16 Bakhtin, 2010, p. 145 
pessoa, porque considerar um momento específico de uma pessoa, seja negativo ou positivo, como um resumo que justifique uma impressão biográfica e definitiva sobre aquela pessoa é um afluente que deságua em uma possibilidade humana errônea: julgar a vida de determinada pessoa por um determinado momento, seja este feliz ou infeliz. A biografia de uma pessoa é composta por vários biografemas. É o que teremos a oportunidade de observar na análise da biografia de Edir Macedo, apresentada nos filmes Nada a perder. Contra tudo. Por todos (2018) e Nada a perder 2. Não se pode esconder a verdade (2019).

\section{Interstícios biográficos: coragem, superação, confiança e amor na cine-vida de Edir Macedo}

Nada a perder. Contra tudo. Por todos (2018) e Nada a perder 2. Não se pode esconder a verdade (2019) são filmes biográficos ${ }^{17}$ baseados na biografia do bispo da Igreja Universal do Reino de Deus, Edir Macedo, cuja própria história de vida, a fé, a polêmica que sempre o acompanhou e o amor - o bispo é amado aos olhos dos fiéis - configuram um mote para sua realização, disposição e/ou sua construção composicional.

O amor cresce na cinebiografia, na história de vida, com base em elementos biográficos, a consciência biográfica social de costumes, mas, sobretudo, a consciência biográfica aventuresco-heroica, que permeia a história de vida do bispo: ora Edir Macedo vive o dia a dia junto aos contemporâneos, ora, em meio à superação, heroifica-se por meio da fé, da busca da glória, da magnanimidade junto aos seus fiéis, e até mesmo - elemento expresso na cinebiografia - de uma generosidade implícita com seus perseguidores.

$\mathrm{Na}$ cinebiografia existem os biografemas que montam a história de vida de um dos maiores líderes religiosos do Brasil, fragmentos da sua vida real, positivos e negativos, que poderiam subsistir independentemente, mas que ganham seu lugar efetivo na construção do todo da biografia de Edir Macedo. Esses biografemas evidentemente confluem para contar a história de vida do idealizador da Igreja Universal do Reino de Deus.

Verificamos já nos títulos dos filmes dirigidos por Alexandre Avancini uma função catafórica. Eles encapsulam os sentidos construídos ao longo das produções e indiciam a jornada heroica que os espectadores irão acompanhar. A parte

17 O filme Nada a perder 2. Não se pode esconder a verdade (2019) é a continuação de Nada a perder. Contra tudo. Por todos (2018) 
Ao homem que sobe montanhas: o amor em meio à polêmica na cinebiografia de Edir Macedo

comum aos dois títulos, "nada a perder", também dá nome aos três volumes da biografia escrita $(2012,2013,2014)$ em que se baseiam seus roteiros. É ela que parece resumir toda a história do bispo, uma história, sobretudo, de coragem. Afirmar não ter nada a perder, no caso de Edir Macedo, equivale a maximizar a importância de uma missão, do propósito para o qual fora chamado.

$\mathrm{O}$ ethos da personagem principal começa a configurar-se desde então; e o primeiro traço desse caráter é a confiança. A segurança de estar a salvo de todos os males que lhe poderão sobrevir é dada pela fé e é isso que lhe garante uma segunda virtude, a coragem. Segundo Aristóteles (1991), a coragem não representa a completa ausência de medo, mas a boa medida entre o medo e a confiança. De qualquer modo, se tiver que se exceder, o corajoso tenderá para a temeridade, e não para a covardia. Ademais, a coragem é virtude que, tornada hábito, tende a avolumar-se: “(...) pois é habituando-nos a desprezar e arrostar coisas terríveis que nos tornamos bravos, e depois de nos tornarmos tais, somos mais capazes de lhes fazer frente". 18

Conforme mencionamos há pouco, frequentemente amamos os corajosos, em especial aqueles que usam sua bravura a favor de nossos interesses, de nossos amigos ou daqueles que acreditamos merecerem. É justamente a essa ideia que nos remete a segunda parte do título do primeiro filme biográfico de Edir Macedo, "Contra tudo. Por todos." Percebemos que, mesmo sendo independentes na aparência por sua configuração sintática, as frases, apresentadas em seu contexto de uso, revelam uma articulação semântica que potencializa o efeito persuasivo. Exatamente por isso, essa é uma configuração encontrada com frequência em slogans publicitários. A justaposição "Contra tudo. Por todos." nos propõe uma adição, "contra tudo $e$ por todos", à qual subjaz também um fim: "contra tudo para que possamos ajudar a todos".

A expressão "Contra tudo" prenuncia, de fato, o enredo, no qual é apresentado ao auditório o princípio da cruzada anti-Edir, que persistirá e se intensificará no segundo filme: políticos, magistrados, imprensa e lideranças da Igreja Católica se unem contra ele. Porém, o objetivo permanece adiante, e é próprio de seu caráter não o abandonar. Já no título da obra, Edir é retratado como um homem disposto ao favor, ao serviço prestado indiferentemente a "todos", o que abarca amigos e inimigos. Isso aumenta ainda mais a excelência de sua virtude, uma vez que "é sinal de favor (...) se se prestaram aos nossos inimigos ou os mesmos serviços, ou então equivalentes ou maiores, pois evidentemente esses não teriam

18 Aristóteles, 1991, p. 32 
sido feitos em nosso interesse". ${ }^{19}$ Antes de começarmos a assistir ao filme, já fomos, portanto, apresentados a uma personagem resoluta e magnânima.

A cinebiografia começa de uma forma interessante, do final para o começo: inicia-se com Edir Macedo, já adulto, sendo preso. ${ }^{20}$ Entretanto, aos moldes de uma biografia canônica, a vida do indivíduo da infância à vida adulta, a cena que se segue é o primeiro biografema da cinebiografia do bispo: o afago da mãe na infância.

Esse biografema se repete ao longo de todo o filme à medida que a polêmica em torno da figura de Edir Macedo vai crescendo, e as acusações e processos vão se acumulando e oprimindo a personagem.

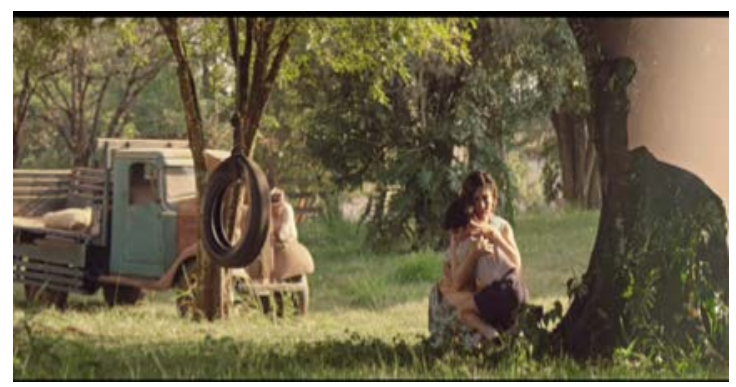

Figura 1 - A criança e sua mãe.

Fonte: Nada a perder. Contra tudo. Por todos (2018)

Nessa cena, o menino Edir Macedo é desafiado a subir numa árvore por outras crianças e cai. Essa é a metáfora que ornamenta as entrelinhas do discurso cinebiográfico do filme: "O homem que sobe as montanhas". A mãe fala ao menino: "Você vai fazer coisas maiores do que subir em árvores, vai subir montanhas" (Figura 1).

Relembrando Lejeune (2014), a criança que representa a infância, ou o adulto a quem se delega esse papel participa de um momento reconstituído, que não são de fato a realidade que querem ser. Na condição de biografema, essa metonímia consiste em um aspecto fragmentário da vida: pormenores que mais interessam da vida a ser refratada. A montanha significaria o topo da vida, que se traduziria na imagem exibida ao final do segundo filme, da subida do bispo ao Monte Sinai, como expressão máxima de sua fé.

19 Aristóteles, 2000, p. 51

20 Biografias escritas como a de Malala Yousafzai começam dessa forma. No caso da autobiografia de Malala, o livro começa pelo atentado sofrido pela a ativista paquistanesa, orquestrado pela milícia extremista Talibã. 
Ao homem que sobe montanhas: o amor em meio à polêmica na cinebiografia de Edir Macedo

A desventura do menino inábil, zombado pelas crianças da vizinhança por uma deficiência física, ${ }^{21}$ é o mote perfeito para a construção da jornada do herói proposta por Campbell (1989). A esse respeito, Helal (1998) observa que as biografias de heróis e ídolos de várias áreas enfatizam situações de abandono, perda ou dificuldades enfrentadas na infância. Essa situação desfavorável é a primeira condição para a superação, que será o ponto alto da saga da personagem. Também é ela que garante uma identificação inicial com o auditório, que, por meio da memória e imaginação, poderá projetar suas próprias dificuldades.

Outro biografema no início do filme 1 conta por meio de seu signo o início da ideia do jovem Edir Macedo no que se refere à Teologia da Prosperidade, constitutiva da Igreja Universal do Reino de Deus. Edir Macedo e seu pai vão a um curandeiro em busca da cura para a asma de sua irmã, e a cena termina com o pagamento em espécie do pai ao benzedeiro. A cura para a irmã não vem, mas no jovem Edir Macedo permanece a ideia da relação religiosa com o dinheiro (Figura 2).

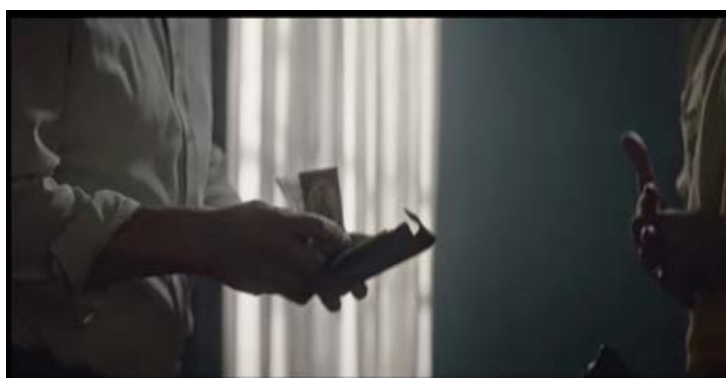

Figura 2 - Pai paga curandeiro.

Fonte: Nada a perder. Contra tudo. Por todos (2018)

Acompanhar a irmã à igreja é uma atitude decisiva na vida de jovem Edir, mas é apenas uma das demonstrações de amor e cuidado para com a irmã doente. $\mathrm{O}$ amor que Edir revela com sua postura zelosa é facilmente percebido pelo auditório e pode, por espelhamento, despertar nos espectadores a mesma paixão. Afinal, quando assistimos a um filme temos a tendência de imitar as emoções que as personagens nos comunicam. Ou seja, quanto mais vemos amor, mais propensos estamos a sentir amor.

Como acredita Pignatari (1996), os biografemas como partes do todo são traços distintivos da biografia: um olhar disperso. É evidente que para se com-

21 Edir Macedo tem uma pequena atrofia na mão esquerda, que afeta a aparência e a mobilidade dos dedos polegar e indicador 
preender as partes da cinebiografia é necessário compreender o todo biográfico. A cinebiografia como um todo goza das duas consciências biográficas propostas por Bakhtin (2010), que trabalham simultaneamente.

A consciência biográfica social de costumes, o homem bom e honesto, aparece no discurso do bispo nos filmes e também no enredo. A boa glória junto aos contemporâneos, um corte social, a humanidade e o cotidiano dos heróis vivos, felicidade ou infelicidade do indivíduo junto aos familiares, seu cotidiano, aparecem na figura da personagem protagonista.

A felicidade ou infelicidade junto aos familiares permeia todo o contexto da cinebiografia. A esposa, Ester Bezerra, acompanha o bispo em toda a sua trajetória ou na maior parte dela. Ester está junto de Edir Macedo em todos os momentos bons e ruins, inclusive em relação à Igreja Universal do Reino de Deus. Entretanto, o amor não se dá na cinebiografia exclusivamente pela relação de Ester e Edir, mas, principalmente, pela relação de Edir Macedo com a construção de sua igreja. Trata-se de um filme centrado não na homogeneidade do casal principal, mas na heterogeneidade, ou seja, na relação de Edir Macedo com vários personagens que circundam sua vida.

Vivendo o cotidiano junto a seus contemporâneos, o bispo Edir Macedo decide viver para pregar o evangelho com o intuito de "salvar almas". E desafios não faltam na trajetória de Macedo. A doença de Viviane, sua filha, abala Edir profundamente e configura um ponto de virada em sua trajetória. Nesse momento da cinebiografia, inicia-se efetivamente a consciência biográfica aventuresco-heroica da personagem: Edir passa a pregar no coreto (Figura 3).

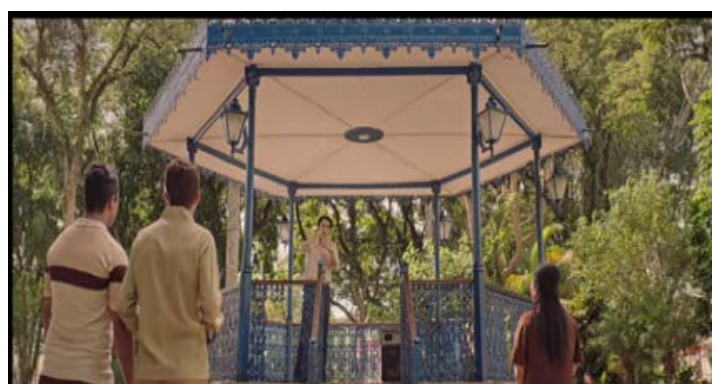

Figura 3 - Primeiras pregações no coreto.

Fonte: Nada a perder. Contra tudo. Por todos (2018)

Edir Macedo abandona o emprego para viver em função de sua fé. Configurar-se-ia uma aventura irresponsável do bispo se não houvesse dado certo. Dessa aventura nasce o herói evangélico da cinebiografia: o homem que tira o diabo do corpo (Figura 4). O mistério e a cura agora são praticados por Macedo em nome de Deus. 
Ao homem que sobe montanhas: o amor em meio à

polêmica na cinebiografia de Edir Macedo

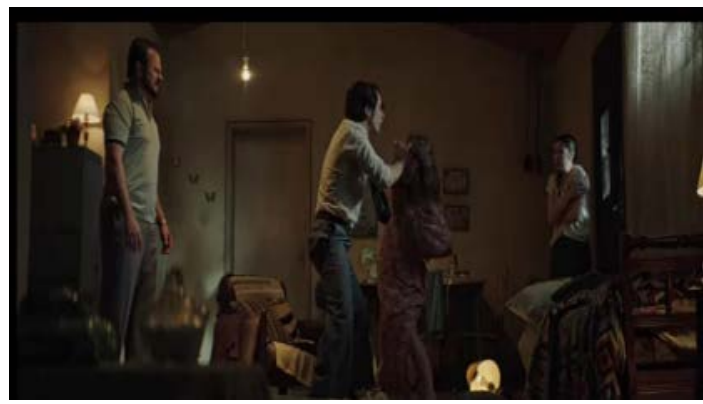

Figura 4 - Exorcismo.

Fonte: Nada a perder. Contra tudo. Por todos (2018)

Como prevê Bakhtin (2010), na consciência biográfica aventuresco-heróica, a personagem se baseia na vontade de ser amado, de ter importância na vida dos outros: deseja ser herói. Trata-se da aspiração à glória junto a contemporâneos e descendentes.

O marido da mulher exorcizada fica absolutamente grato ao bispo, que passa a ter uma informação de si mesmo na consciência amorosa do outro. Edir Macedo supera a si mesmo pela adesão da consciência amorosa do outro.

Depois do exorcismo, Edir Macedo passa a realizar sucessivas façanhas. De homem comum, torna-se uma figura excepcional. De qualquer maneira, a convivência com os outros personagens, seus contemporâneos, não é abandonada no roteiro de Nada a perder. Contra tudo. Por Todos. Um biografema importante da biografia do bispo é compartilhado com o empresário, ícone da televisão brasileira, Ś́lvio Santos. Esse biografema encenado na cinebiografia de Edir Macedo é parte tanto da biografia do líder da Igreja Universal do Reino de Deus quanto da biografia do dono do SBT. Ambos protagonizaram a compra e venda da TV Record.

$\mathrm{Na}$ cena em que negocia a compra da Record com Súlvio Santos, Edir Macedo aparece como homem bom e honesto: um orador sincero, digno de confiança. É assim que convence Ślvio e seus sócios a lhe venderem a emissora (Figura 5). 


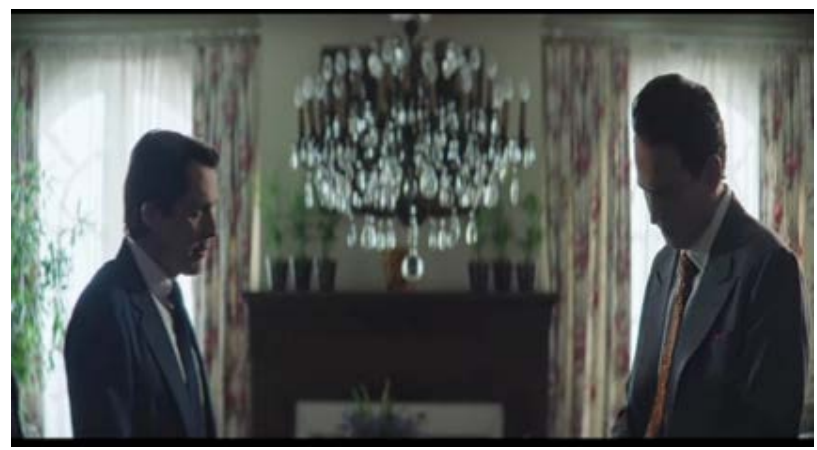

Figura 5 - Proposta de Edir Macedo a Silvio Santos para a compra da Record. Fonte: Nada a perder. Contra tudo. Por todos (2018)

A confiança e a coragem de Edir surpreendem, mas no roteiro de Nada a perder sempre fica claro que o destino do bispo está entregue nas mãos de Deus e que todas as suas ações cooperam para a divulgação do Seu nome.

O herói aparece de forma velada no decorrer de todo o filme, por exemplo, com a ajuda aos mais necessitados, mas é na prisão do bispo que acontece a expressão máxima de heroísmo no filme (Figura 6). Edir é acusado de charlatanismo, estelionato e curandeirismo, e permanece preso por onze dias.

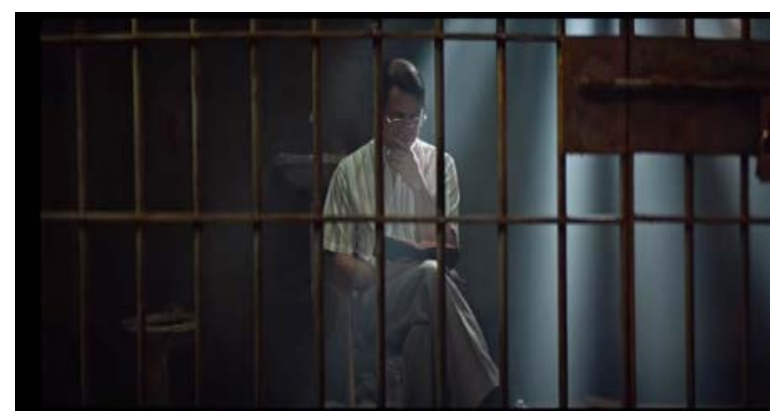

Figura 6 - Lendo a Bíblia na prisão.

Fonte: Nada a perder. Contra tudo. Por todos (2018)

Em meio a toda aparente injustiça que Edir Macedo sofre, ele continua amoroso, em paz, mas, sobretudo, absolutamente resiliente. Isso configura uma escolha um pouco exagerada por parte do diretor do filme - Alexandre Avancini -, entretanto, os heróis, especialmente os cinematográficos são assim. 
Ao homem que sobe montanhas: o amor em meio à polêmica na cinebiografia de Edir Macedo

Edir Macedo, assim como Indiana Jones, que nunca perde seu chapéu, jamais perde sua fé.

O bispo-herói se solidifica no final do filme 1.

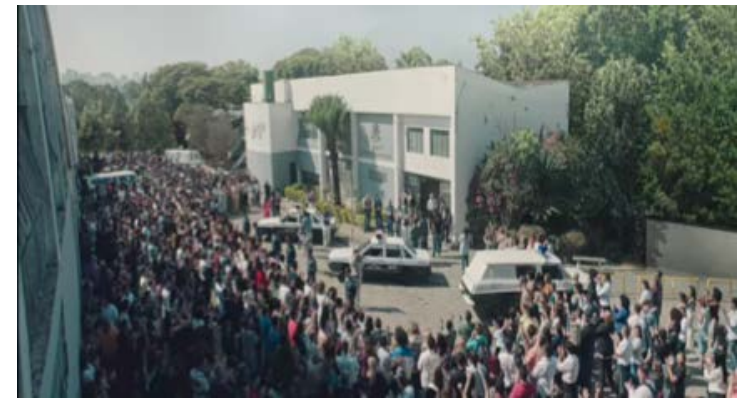

Figura 7 - Falando aos fiéis na delegacia.

Fonte: Nada a perder. Contra tudo. Por todos (2018)

Essa cena da delegacia goza de um discurso do bispo que transmite calma. Os ânimos estão sobressaltados, e os policiais temem que os manifestantes da Igreja Universal do Reino de Deus, reunidos à frente da delegacia (Figura 7), ajam com violência. Edir Macedo se prontifica a falar com eles: "Não vai acontecer nada, vou falar com eles". O discurso da personagem é um discurso de amor. O bispo demostra consciência e benevolência com seu povo e com os policiais.

A cinebiografia propõe Edir Macedo como um herói desenhado nesse momento de tensão na delegacia: uma ocasião de fundamental importância da vida privado-social, privado-cultural e privado-histórica do bispo preso. Trata-se de um momento da sua biografia em que amou e sentiu-se amado: os fiéis da Igreja Universal do Reino de Deus fizeram companhia ao bispo e deram todo apoio naquele momento difícil. Valores ligados à honradez, generosidade e magnanimidade materializaram a forma biográfica aventuresco-heroica.

Nada a perder 2. Não se pode esconder a verdade (2019) dá sequência à saga de Macedo. Nessa produção, a segunda parte do título, "Não se pode esconder a verdade", também revela boa parte do que o longa-metragem nos reserva. $\mathrm{O}$ segundo filme apresenta uma clara defesa de Edir Macedo às acusações que lhe foram dirigidas nas últimas décadas. Não se pode esconder a verdade é, mais que uma afirmação, uma promessa. Há algo que precisa ser dito, que precisa ser esclarecido em relação às polêmicas que cercam a vida do bispo e a Igreja Universal do Reino de Deus. 
A cinebiografia revisita o momento em que Edir Macedo deu a entrevista para a composição de sua biografia (Figura 8). Nesse ensejo da cinebiografia aparece o sujeito autobiográfico, donde a narração do personagem Edir Macedo invade a fronteira e toma parte na cena de outros personagens para narrar. Em algumas ocasiões, ele usa a $1^{\text {a }}$ pessoa do plural, "nós". Em outras ocasiões, a $1^{\text {a }}$ pessoa do singular, "eu": o orador - enunciador - se funde ao enunciado.

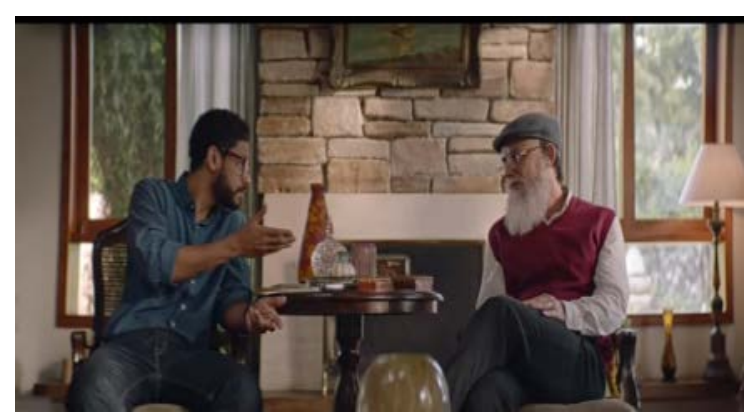

Figura 8 - Entrevista de Macedo para a biografia.

Fonte: Nada a perder 2. Não se pode esconder a verdade (2019)

Nada a perder. Contra tudo. Por todos (2018) é estritamente em $3^{\text {a }}$ pessoa. Nada a perder 2. Não se pode esconder a verdade (2019) intercambia posições. Não raro o sujeito autobiográfico - Edir Macedo mais velho dando a entrevista - adentra as cenas para narrar a partir do seu ponto de vista.

Por certo, a "edição" da história de Macedo superdimensiona certos atos, dá a alguns uma relevância secundária, e omite tantos outros. No entanto, são apresentadas discussões sobre questões controversas, como a origem da fortuna do bispo e o "chute" na imagem de Nossa Senhora Aparecida, dado pelo pastor Sérgio von Helder no dia da santa padroeira do Brasil, em um programa de TV.

Para comprovar a inocência de Edir e evitar que as paixões contrárias a ele, retratadas no filme, contaminem o auditório, são fornecidas explicações para cada uma das polêmicas, as quais afirmam a honestidade e a responsabilidade do bispo para com a sua obra e seu rebanho; bem como apresentadas cenas em que políticos, juízes e líderes religiosos tramam estratégias para prejudicá-lo.

Em um dos pronunciamentos feitos em tempos de crise, logo após o episódio do "chute na santa", Macedo faz uma longa exposição sobre o amor, paixão que, segundo ele, norteia as ações da Igreja Universal do Reino de Deus:

Nós, da Igreja Universal do Reino de Deus, jamais aceitamos qualquer coisa que venha a manifestar revolta entre as pessoas. Pelo contrário, nós pregamos o amor. E vivemos o amor. E procuramos levar o amor 
Ao homem que sobe montanhas: o amor em meio à

e a compreensão a todas as pessoas, quer sejam católicos, espíritas, evangélicos, budistas, de qualquer religião. ${ }^{22}$

E segue, citando 1Co:

Ainda que eu distribua todos os meus bens entre os pobres, se eu não tiver amor, de nada me aproveitará. $\mathrm{O}$ amor tudo sofre, tudo crê, tudo espera, tudo suporta. E assim tem sido a Igreja Universal do Reino de Deus. Tudo nós temos suportado, todas as injustiças, as infâmias, as perseguições. Mas tudo isso nós aprendemos a suportar porque assim também aconteceu com o Nosso Senhor Jesus. E de maneira nenhuma, jamais, em tempo algum, procuramos revidar, mostrar a nossa fé com atos inconsequentes e desastrosos como esse que aconteceu na quinta-feira passada [referindo-se ao episódio protagonizado pelo pastor Sérgio von Helder]. ${ }^{23}$

Decerto, o discurso do bispo não se dirige apenas ao auditório diegético, mas também àquele que assiste ao filme. A imagem do homem humilde, afável e complacente não diminui, contudo, o heroísmo do personagem. Macedo é um herói que se sacrifica para ser glorificado pelo Pai, a exemplo do próprio Cristo. Por meio da comparação com Jesus, o bispo tem a sua excelência moral amplificada, o que enfatiza a injustiça cometida por seus opositores e, consequentemente, intensifica o sofrimento do bispo e de seus fiéis, o que, no extremo, poderia levar o auditório à piedade, já que essa paixão refere-se a “(...) um certo pesar por um mal destrutivo ou penoso, e atinge quem não o merece (...)"."24

Todavia, a comparação entre Edir Macedo e grandes figuras religiosas não para por aí. No momento de maior tensão da história, quando parece não existir mais solução possível para os problemas que se acumulam na vida do bispo, Macedo resolve viajar ao Monte Sinai, onde Deus, segundo a Bíblia, falou a Moisés. No topo do monte, o bispo se entrega ao mistério e se lembra da profecia da mãe: ele, enfim, subia montanhas. A cena seguinte, na qual o pastor queima os seus processos, é a redenção do herói.

A glória definitiva de Edir Macedo vem, no entanto, com a construção do Templo de Salomão. A recapitulação que acontece antes de Edir subir ao altar na inauguração do Templo é típica da peroração, parte final do discurso persuasivo, e abrange cenas

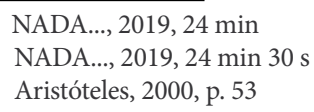


apresentadas nos dois filmes. É, com efeito, o momento de exaltação de Macedo: os pequenos passos e todos os desafios superados o conduziram a esse instante.

Há, nesse momento, uma mudança significativa: passam a ser exibidas imagens reais da inauguração do templo. Os atores saem de cena e nos deparamos com o "verdadeiro" Edir e com o seu "verdadeiro" auditório. A possibilidade do intercâmbio se coloca como uma estratégia retórica contundente. A troca do Edir Macedo "ficcional" pelo "real" favorece a percepção de que tudo o que foi exibido até então é a mais pura verdade. Para esse efeito, colabora a caracterização do ator Petrônio Gontijo, que interpreta Edir Macedo. A semelhança entre os dois permite que a troca entre as cenas ficcionais e reais se dê com sutileza e materialize diante de nossos olhos uma vida, de fato, espetacular.

\section{Considerações finais}

"No palco contemporâneo, o espetáculo em cartaz é a vida". ${ }^{25}$ A sociedade midiatizada, em que impera a encenação do real, produz mecanismos de realimentação da ilusão pela contínua produção de ídolos. Alguns deles, como vimos na análise da cinebiografia de Edir Macedo - "baseada em fatos reais", como nos é informado no início do primeiro filme - se aproximam dos heróis. Não podendo ser cantados por poetas, escrevem autobiografias, nas quais podem exaltar sua virtude, sua honra, suas conquistas, sua missão, entre outras características extraordinárias de suas personalidades.

Dentre os pares, o herói contemporâneo ainda é o melhor, aquele que possui os atributos necessários para representá-los. Edir representa, mais que a si, à sua igreja. E por mais dramáticos que sejam os acontecimentos, seu destino está sob controle e já previsto. A vitória é garantida, e não é exclusivamente sua, mas de todos os que estão ao seu lado, ou que algum dia poderão estar, quando compreenderem a verdade. Desse modo, Macedo propõe o amor sob diferentes formas.

$\mathrm{Na}$ cinebiografia do bispo não faltam mostras de um amor baseado no desejo, na busca por aquilo que nos falta, como afirma Platão: “(...) deseja o que não está à mão nem consigo, o que não tem, o que não é ele próprio e o de que é carente; tais são mais ou menos as coisas de que há desejo e amor (...)", ${ }^{26}$ o que, em certa medida, impele à esperança e à coragem. Há também, sem dúvida, o amor como alegria no desfrutar, conforme Spinoza (2009): a alegria 
Ao homem que sobe montanhas: o amor em meio à polêmica na cinebiografia de Edir Macedo

em contar com a família, em estar com os amigos, em cumprir o seu destino, em assumir o seu lugar no altar, à frente de poucos ouvintes ou de multidões. $\mathrm{O}$ amor que aumenta a potência de existir. E, finalmente, um amor inspirado no amor divino, a agapé cristã, explicada por Nygren (1982): espontânea, gratuita, sem interesse ou justificação. É o amor que renuncia, se limita, se sacrifica para que seu objeto, não limitado àqueles que nos fazem bem, tenha espaço para ser. É, definitivamente, o amor que liberta.

Independentemente de opiniões prévias sobre a personagem principal dos filmes, o que a cinebiografia de Edir Macedo nos apresenta é a história "real" de um homem incomum, que tem no amor o princípio e o fim de suas ações, já que todas elas são determinadas pela vontade de Deus, que é puro amor. Partindo-se dessa perspectiva, a retribuição mais provável do auditório - embora não seja a única possível - é também o amor. A personagem biografada chega, assim, ao objetivo previsto por Bakhtin (2010): instaurar-se na consciência amorosa dos seus contemporâneos e, por que não, da posteridade.

\section{Referências}

ARISTÓTELES. Ética a Nicômaco. In: ARISTÓTELES. Ética a Nicômaco; Poética. São Paulo: Nova Cultural, 1991. (Os pensadores, v. 2)

ARISTÓTELES. Retórica das paixões. Trad. Isis Borges B. da Fonseca. São Paulo: Martins Fontes, 2000.

ARISTÓTELES. Retórica. Trad. Manuel Alexandre Júnior, Paulo Farmhouse Alberto e Abel do Nascimento Pena. Lisboa: Universidade de Lisboa/Imprensa Nacional - Casa da Moeda, 2005.

BAKHTIN, M. Estética da criação verbal. Trad. Paulo Bezerra. São Paulo: Martins Fontes, 2010.

BARTHES, R. Sade Fourier Loiola. Trad. Maria de Santa Cruz. São Paulo: Martin Fontes, 1971.

BÍBLIA. Português. Bíblia Sagrada. Tradução TEB - Tradução Ecumênica da Bíblia. São Paulo: Loyola/Paulinas, 1995.

CAMPBELL, J. O herói de mil faces. Trad. Adail Ubirajara Sobral. São Paulo: Cultrix/ Pensamento, 1989.

DEBORD, G. A sociedade do espetáculo. Trad. Estela dos Santos Abreu. Rio de Janeiro: Contraponto, 1997.

GABLER, N. Vida, o filme: como o entretenimento conquistou a realidade. Trad. Beth Vieira. São Paulo: Companhia das Letras, 1999. 
HELAL, R. Cultura e idolatria: ilusão, consumo e fantasia. In: ROCHA, E. (org.). Cultura \& imaginário: interpretação de filmes e pesquisa de ideias. Rio de Janeiro: Mauad, 1998. p. 135-150.

LE BRETON, D. As paixões ordinárias: antropologia das emoções. Trad. Luís Alberto Salton Peretti. Petrópolis, RJ: Vozes, 2009.

LEJEUNE, P. O pacto autobiográfico: de Rousseau a internet. Trad. Jovita Maria Gerheim Noronha, Maria Inês Coimbra Guedes. Minas Gerais: UFMG, 2014.

MACEDO, Edir. Nada a perder. Momentos de convicção que mudaram a minha vida. São Paulo: Planeta, 2012.

MACEDO, Edir. Nada a perder 2. Meus desafios diante do impossível. São Paulo: Planeta, 2013.

MACEDO, Edir. Nada a perder 3. Do coreto ao Templo de Salomão: a fé que transforma. São Paulo: Planeta, 2014.

MAGALHÃES, A. L. Medo, humor e ética no filme Relatos Selvagens. In: FIGUEIREDO, M. F.; FERREIRA, F. A.; RODRIGUES-ALVES, M. S. (org). O animal que nos habita: a retórica das paixões em Relatos Selvagens. Franca, SP: UNIFRAN, 2016. p.19-34.

MEYER, M. Prefácio: Aristóteles ou a retórica das paixões. In: ARISTÓTELES. Retórica das paixões. Trad. Isis Borges B. da Fonseca. São Paulo: Martins Fontes, 2000. p. XVII-LI.

MUNSTERBERG, H. As emoções. Trad. Teresa Machado. In: XAVIER, Ismael (org.). A experiência do cinema: antologia. Rio de Janeiro: Graal/Embrafilme, 1983. p. 46-54.

NADA a perder. Contra tudo. Por todos. Direção de Alexandre Avancini. São Paulo: Paris Filmes, 2018. (132 min.)

NADA a perder 2. Não se pode esconder a verdade. Direção de Alexandre Avancini. São Paulo: Paris Filmes, 2019. (96 min.)

NYGREN, A. Agape and Eros. Translated by Philip S. Watson. Chicago, USA: University of Chicago Press, 1982.

PENA, F. Teoria da biografia sem fim. Rio de Janeiro: Mauad, 2004.

PIGNATARI, D. Para uma semiótica da biografia. In: HISGAIL, F. (org.). Biografia: sintoma da cultura. São Paulo: Hacker Editores/Cespuc, 1996. p.13-19.

PLATÃO. O banquete. Trad. José Cavalcante de Souza. In: PLATÃO. Diálogos. Trad. José Cavalcante de Souza, Jorge Paleikat e João Cruz Costa. São Paulo: Nova Cultural, 1991. p. 32-102. (Os pensadores)

SPINOZA, B. de. Ética. Trad. Tomaz Tadeu. Belo Horizonte: Autêntica, 2009.

VILAS BOAS, S. Biografismo: reflexão sobre as escritas da vida. São Paulo: UNESP, 2007. 